\title{
Phenotypic Diversity in Arabica Coffee Genotypes from Eastern Ethiopia
}

\author{
Abdi Adem ${ }^{1, ~ *, ~ H u s s e i n ~ M o h a m m e d ², ~ A m s a l u ~ A y a n a ~}{ }^{3}$ \\ ${ }^{1}$ Department of Horticulture, College of Agriculture and Natural Resource, Dilla University, Dilla, Ethiopia \\ ${ }^{2}$ School of Plant Science, College of Agriculture, Hawwasa University, Hawwasa, Ethiopia \\ ${ }^{3}$ Integerated Seed Sector Development (ISSD) for Ethiopia, Addis Ababa, Ethiopia
}

Email address:

abdi.ademame@gmail.com(A. Adem)

*Corresponding author

\section{To cite this article:}

Abdi Adem, Hussein Mohammed, Amsalu Ayana. Phenotypic Diversity in Arabica Coffee Genotypes from Eastern Ethiopia. International Journal of Ecotoxicology and Ecobiology. Vol. 5, No. 4, 2020, pp. 42-47. doi: 10.11648/j.ijee.20200504.11

Received: September 19, 2020; Accepted: September 29, 2020; Published: October 30, 2020

\begin{abstract}
This study was conducted with objective to determine extent of phenotypic diversity in Arabica coffee accessions from Eastern Ethiopia. Treatments consisted of 49 coffee accessions. The accessions were field planted at Mechara Agricultural Research Center in July, 2005 using simple lattice design with two replications. Total of 15 quantitative characters were recorded using standard coffee descriptors. The collected data were subjected to SAS software for Analysis of variance. Cluster analysis was also done. Mean squares due to coffee accessions were highly significant $(p<1 \%)$ for all quantitative characters studied except for number of internodes of main stem and average length of primary branch, indicating the presence of remarkable phenotypic variation among the coffee accessions studied. For stem characters, plant height varied from 94.00 to $165.40 \mathrm{~cm}$; number of internodes of main stem ranged from 17.90 to $24.80 \mathrm{~cm}$; internode length of main stem varied from 5.30 to $8.25 \mathrm{~cm}$; diameter of main stem from 3.40 to $5.35 \mathrm{~cm}$. For branch characters, number of primary branches ranged from 30.20 to 43.10; length of primary branch from 43.10 to $105.10 \mathrm{~cm}$; numbers of internodes of primary branch 14 to 26.70; internode length of primary branch was from 3.20 to $5.73 \mathrm{~cm}$; numbers of secondary branch varied from 41.10 to 133.20 . For leaf characters, leaf length varied from $9.20 \mathrm{~cm}$ to $18.43 \mathrm{~cm}$ and with mean of $13.40 \mathrm{~cm}$. Leaf width from 3.49 to $8.77 \mathrm{~cm}$ with mean vale of $6.24 \mathrm{~cm}$. Average leaf area of all accessions was 57.96 with variation from 24.63 to $105.45 \mathrm{~cm}^{2}$. Weight of hundred beans ranged from 11 $\mathrm{g}$ for five accessions (H-25/04, H-40/04, H-41/04 and H-618/ 98) to 16.5 for H03/04 with mean value of $13.53 \mathrm{~g}$. Cluster analysis grouped the coffee accessions into five groups of different sizes, ranging from one entry in cluster IV and V to 34 in cluster I. Inter-cluster distances were highly significant $(\mathrm{p}=0.01)$ except between cluster I and II, indicating presence of considerable phenotypic diversity in coffee accessions from eastern Ethiopia. It is advisable to maintain and evaluate the coffee genotypes for disease resistance, moisture stress tolerance, yield and cup quality in future studies.
\end{abstract}

Keywords: Arabica Coffee, Cluster Analysis, Eastern Ethiopia, Morphological Characters

\section{Introduction}

Coffee is a major cash crop in Ethiopia. In 2018, the country earned 839 million dollar from coffee export accounting for close to $30 \%$ income generated from all export commodities [1]. It is a means of livelihood for about 25 million people in the country. The country ranks $5^{\text {th }}$ from world and $1^{\text {st }}$ from Africa in coffee production [2]. Ethiopia is the center of origin and diversity for Arabica coffee [3]. Coffee research in Ethiopia was started in 1960s. But So far, only 40 (34 pure line and 6 hybrid) coffee varieties were released for production in different parts of the country. Efforts have been made to conserve the germplasm since 1967. Total of 12,654 Arabica coffee germplasm have been ex-situ conserved in field gene banks in the country [4]. Forty varieties (34 pure lines and 4 hybrids) were developed from collections and released for production in different parts of the country In Hararge, Eastern Ethiopia, coffee is grown in diversified garden production systems. The crop is intercropped with maize, sorghum, beans, sweet potato and "chat" (Chata edulis). Hararge, eastern Ethiopia is known for production of best quality coffee known 
as Harar coffee [5]. Farmers grow coffee landraces having their own characteristic features. Number [6] recorded about 22 named coffee landraces in Hararge. In an effort to develop improved coffee varieties for the area, germplasm collection campaigns have been under taken since 1998. In 2004, 47 coffee accessions were collected from the area and maintained for evaluation at Mechara Agricultural Research Center. Genetic data are important for designing effective plant breeding programs. Genetic diversity assessment methods could be categorized as morphological, biochemical and molecular markers. Of these, morphological characterization is considered as the first step in description and classification of crop germplasm [22]. It is also used for variety registration in Ethiopia. Accordingly, this study was conducted with objective to determine status of phenotypic diversity in coffee accessions from Eastern Ethiopia.

\section{Materials and Methods}

\subsection{Description of Experimental Site}

The study was conducted at the Mechara Agricultural Research Center in 2009. The Center is located at $8^{\circ} 36^{\prime} 38.1^{\prime \prime}$ North latitude, $40^{\circ} 19^{\prime} 29.8^{\prime \prime}$ East longitude and at an altitude of about 1800 meter above sea level. It is situated at $434 \mathrm{~km}$ east of Addis Ababa, capital of Ethiopia and $110 \mathrm{~km}$ south of Chiro town, Zonal Town. The soil of the centre is deep, well-drained and slightly acidic soil and thus suitable for arabica coffee production. The area receives an annual rainfall of $1100 \mathrm{~mm}$, of which about $85 \%$ is received from June to September, while the remaining amount is received from February to April. The annual average minimum and maximum temperature of Mechara are $14^{\circ} \mathrm{C}$ and $26^{\circ} \mathrm{C}$, respectively.

\subsection{Treatment and Experimental Design}

Total of 49 Arabica coffee accessions consisting of 47 accessions collected in 2004, one accession collected in 1998 from West Harerge Zone district, Eastern Ethiopia and one improved variety from south-west part of Ethiopia. The 48 coffee accessions were collected from different coffee grower areas: Aba Aman (8), Bereka (3), Jeneti (6), Selama (4), Sham (18), Waltasis (8) and Oda Bultum district (1). The accessions were collected from altitude ranging from 1650 to 1916 m.a.s.l All accessions were field planted in July, 2005 using simple lattice $(7 \times 7)$ design with two replications and are currently under evaluation for variety development. The trees were planted with spacing of $2 \mathrm{~m}$ between plants and $3 \mathrm{~m}$ between blocks. Field management practices were applied to all plots uniformly as per recommendation.

\subsection{Data Collection and Analysis}

Total 15 quantitative morphological characters were collected at second bearing stage (at the age of four years from planting). Standard coffee descriptors of International Plant Genetic Research Institute [26] were used for data recording. The data collected included plant height $(\mathrm{cm})$; Number nodes of main stem; Inter-node length of main stem (cm); Stem diameter $(\mathrm{cm})$; No. of primary branches per plant; Length of primary branches $(\mathrm{cm})$; No. of internodes of primary branches; Inter-node length of primary branches $(\mathrm{cm})$; No. of secondary branches; Leaf length $(\mathrm{cm})$; Leaf width $(\mathrm{cm})$; Leaf area $\left(\mathrm{cm}^{2}\right)$; Canopy diameter (cm); Hundred coffee bean weight (g) and Yield per tree $(\mathrm{g})$. All data were recorded from five randomly selected sample plants per plot, excluding border plants.

Analysis of variance (ANOVA) was computed using SAS software [20]. Least significant difference (LSD) test at 5\% probability level was used for mean separation. Clustering analysis was done to separate the 49 coffee accessions in to different groups using SAS based on the generalized $\mathrm{D}^{2}$ distances by average linkage method of hierarchical clustering called Un-weighted pair group methods with arithmetic average (UPGMA). Appropriate number of clusters was determined from the values of pseudo $F$ and pseudo T2 statistics calculated by SAS. Cluster analysis divides data in to meaningful groups based on the information found in the data that describes the genotype and their relationship [14].

Genetic distance between clusters was also calculated using the generalized Mahalanobis's $D^{2}$ statistics. The $\mathrm{D}^{2}$ value obtained for pairs of clusters was considered as the calculated value of Chi-square $\left(\chi^{2}\right)$ and was tested for significance at the required level of probability against the tabulated values of $\chi^{2}$ for $p$ degrees of freedom, where $p$ is the number of characters considered [21]. SAS software was employed for the analysis. The $\mathrm{D}^{2}$ is defined as: $\mathrm{D}^{2} \mathrm{ij}=(\mathrm{Xi}-\mathrm{Xj}) 1 \mathrm{~S}^{-1}(\mathrm{Xi}-\mathrm{Xj})$; Where, $\mathrm{D}^{2}{ }_{\mathrm{ij}}=\mathrm{is}$ the distance between two groups $\mathrm{i}$ and $\mathrm{j}$; $\mathrm{Xi}$ and $\mathrm{Xj}$ are the two vector mean of the traits for $i^{\text {th }}$ and $j^{\text {th }}$ groups respectively, and $\mathrm{S}^{-1}$ is the inverse of the pooled covariance [16].

\section{Result and Discussion}

\subsection{Analysis of Variance}

Mean squares due to accessions were highly significant $(p<0.01)$ for all the quantitative characters studied except for number of internodes of main stem and average length of primary branch (Table 1), suggesting the presence of substantial variability among the 49 coffee accessions studied. Variation among accessions in some traits was also revealed by big difference between minimum and maximum values as well as high standard error (Table 2).

For stem characters, plant height varied from 94.00 to $165.40 \mathrm{~cm}$; number of internodes of main stem ranged from 17.90 to $24.80 \mathrm{~cm}$; internode length of main stem varied from 5.30 to $8.25 \mathrm{~cm}$; diameter of main stem from 3.40 to $5.35 \mathrm{~cm}$. Genotype H26/04 was significantly taller $(165.4 \mathrm{~cm})$ followed by $\mathrm{H}-19 / 04(163.1 \mathrm{~cm}), \mathrm{H}-618 / 98(162.2 \mathrm{~cm})$ and $\mathrm{H}-11 / 04$ $(159.9 \mathrm{~cm})$. Non-significant differences among accessions were observed for number of internodes on main stem (NIMS). However, among all accessions tested, H-41/04 had the greater number of internode (24.8), followed by H-25/04 (23.8), H-29/04 (23.6) and H-11/04 (23.5). Coffee genotype $\mathrm{H}-20 / 04$ had significantly the longest internodes of main stem 
$(8.25 \mathrm{~cm})$ as compared to all other accessions, followed by $\mathrm{H}-19 / 04(7.91 \mathrm{~cm}), \mathrm{H}-26 / 04(7.86 \mathrm{~cm})$ and H-48/04 $(7.8 \mathrm{~cm})$. Similarly, accessions were significantly different for their diameters on main stem. Of the tested accessions, H-19/04 had highly significant and the thickest diameter of main stem $(5.35$ $\mathrm{cm})$, followed by H-08/04 $(5.33 \mathrm{~cm}), \mathrm{H}-15 / 04(5.25 \mathrm{~cm})$ and $\mathrm{H}-26 / 04(5.2 \mathrm{~cm})$.

For branch character, number of primary branches ranged from 30.20 to 43.10 ; length of primary branch from 43.10 to $105.10 \mathrm{~cm}$; numbers of internodes on longest primary branch from 14 to 26.70; internode length of primary branch from 3.20 to $5.73 \mathrm{~cm}$; numbers of secondary branch from 41.10 to 133.20 .

Differences between minimum and maximum values for other characters were also big. Accession H-41/04 had significantly more number of primary branches (43.1) per tree compared to all other accessions followed by H-25/04 (42.3), $\mathrm{H}-11 / 04$ (42.1) and H-29/04 (40.9). Accessions were significantly different for length of primary branches. Among all accessions, H-16/04 had significantly the longest (105.1 $\mathrm{cm})$ primary branch, followed by $\mathrm{H}-20 / 04$ (99.4) and $\mathrm{H}-23 / 04$ (99.2). Similarly, number of secondary branches of genotype the H-09/04 was significantly the highest (133.2) when compared to the other accessions, followed by H-17/04 (112.5), H-11/04 (111.5) and H-13/04 (109.1). Leaf characters also manifested significant differences among the accessions considered. Leaf length was from $9.20 \mathrm{~cm}$ to $18.43 \mathrm{~cm}$ and with mean of $13.40 \mathrm{~cm}$. similarly, leaf width varied from 3.49 to $8.77 \mathrm{~cm}$ with mean vale of $6.24 \mathrm{~cm}$. Average leaf area of all accessions was $57.96 \mathrm{~cm}^{2}$ with range from $24.63 \mathrm{~cm}^{2}$ to
$105.45 \mathrm{~cm}^{2}$. Number $[2,6,11,8,12,13,20,25]$ reported similar results.

Regarding bean characters and yield, weight of hundred beans ranged from $11 \mathrm{~g}$ for five accessions (H-25/04, H-40/04, $\mathrm{H}-41 / 04$ and $\mathrm{H}-618 / 98)$ to 16.5 for $\mathrm{H} 03 / 04$ with mean value of $13.53 \mathrm{~g}$. There was no significant difference between accession (H-03/04) with the biggest bean weight and other 11 accessions (H-40/04, H-41/04, H618/98, H-17/04, H-24/04, H-31/04, H-33/04, H-37/04, H-39/04 and H-18/04). Similarly, accessions with smallest bean weight were H-03/04, H09/04, H-16/04, H-26/04 and H-38/04.

On the other hand, accession $\mathrm{H}-11 / 04$ gave significantly the highest average green bean yield (176.39 $\mathrm{g} /$ tree) as compared to all the other accessions followed by H-25/04 (146.22 g/tree), H-618/98 (140.21 g/tree), H-21/04 (131.85 g/tree) and $\mathrm{H}-18 / 04$ (123.70 g/tree). The study further indicated that accession $\mathrm{H}=11 / 04$, was the highest yielder and it can be advanced to the next breeding program though the other desirable traits remain for future studies. The coffee genotype 74110 (check) showed the least value for 13 of the 16 quantitative characters considered. The reasons for the low yield in the present study could be due to age of the coffee accessions and physiological disorder caused by moisture stress during dry season.

Most of the findings of the present study are in agreement with previous studies [9, 23]. According to [9], leaf length of Coffea arabica varied from 9.8 to $13.7 \mathrm{~cm}$; leaf width from 3.8 to $5.9 \mathrm{~cm}$. Similarly, [23] reported values ranging between 10 to $15 \mathrm{~cm}$ for leaf length, 4 to $6 \mathrm{~cm}$ for leaf width, 0.15 to $0.20 \mathrm{~g}$ for bean weight among arabica coffee accessions.

Table 1. ANOVA table of 15 quantitative characters of coffee accessions at Mechara.

\begin{tabular}{|c|c|c|c|c|c|c|c|c|c|}
\hline SV & DF & $\mathbf{P H}$ & NIMS & ILMS & SD & NPB & LPB & NIPB & ILPB \\
\hline Rep & 1 & $973.48 * *$ & $122.13 * *$ & $5.27 * *$ & $10.97 * *$ & $687.68 * *$ & $14.58^{\mathrm{NS}}$ & $50.07 * *$ & $1.42 * *$ \\
\hline Genotype & 48 & $298.66^{* *}$ & $4.24^{\mathrm{NS}}$ & $0.66 * *$ & $0.43 * *$ & $17.54 * *$ & $201.92 * *$ & $11.67 * *$ & $0.53 * *$ \\
\hline Error & 48 & 115.39 & 2.76 & 0.11 & 0.10 & 7.90 & 49.10 & 2.34 & 0.12 \\
\hline CV (\%) & & 7.37 & 7.97 & 4.66 & 6.75 & 7.77 & 7.97 & 7.25 & 8.15 \\
\hline $\mathrm{R}^{2}(\%)$ & - & 73.43 & 71.07 & 87.6 & 86.91 & 80.13 & 80.47 & 84.44 & 82.66 \\
\hline
\end{tabular}

Table 1. Continue.

\begin{tabular}{|c|c|c|c|c|c|c|c|c|}
\hline SV & DF & NSB & $\mathbf{L L}$ & LW & LA & CD & HBW & YLD \\
\hline Rep & 1 & $5599.84 * *$ & $3.46 * *$ & $7.32 * *$ & $77.08 * *$ & $877.51^{*}$ & $0.69^{\mathrm{NS}}$ & $114.75^{*}$ \\
\hline Genotype & 48 & $749.32 * *$ & $6.58 * *$ & $2.21 * *$ & $503.24 * *$ & $564.90 * *$ & $5.29 * *$ & $2868.6 * *$ \\
\hline Error & 48 & 269.34 & 0.01 & 0.01 & 0.01 & 179.02 & 0.22 & 168.28 \\
\hline CV (\%) & & 22.51 & 0.22 & 0.90 & 0.27 & 9.95 & 3.43 & 19.67 \\
\hline $\mathrm{R}^{2}(\%)$ & - & 76.28 & 99.99 & 99.87 & 99.99 & 76.51 & 96.10 & 94.46 \\
\hline
\end{tabular}

Abbreviation: PHT- plant height; NIMS- number of internodes of main stem; ILMS- internode length of main stem; SD- Stem diameter; NPB- number of primary branches; LPB- length of primary branch; NIPB- number of internodes of primary branch; ILPB- internode length of primary branch; NSB- number of secondary branches; LL- leaf length; LW=leaf width; LA- leaf area; CD- canopy diameter; HBW- hundred bean weight and YLD- yield per plant.

* indicates significant at 5\%, ** indicates significant at $1 \%$ level of probability; NS- non-significant.

Table 2. Ranges and means values of 15 quantitative characters for 49 coffee accessions.

\begin{tabular}{|c|c|c|c|c|c|c|}
\hline SN & Traits & Min & $\operatorname{Max}$ & Range & Mean & CV (\%) \\
\hline 1 & Plant height $(\mathrm{cm})$ & 94.00 & 165.4 & 71.40 & 145.81 & 7.37 \\
\hline 2 & Number of internode of main stem & 17.90 & 24.80 & 6.90 & 20.84 & 7.97 \\
\hline 3 & Internode length of main stem $(\mathrm{cm})$ & 5.30 & 8.25 & 2.95 & 7.06 & 4.60 \\
\hline 4 & Stem diameter $(\mathrm{cm})$ & 3.40 & 5.33 & 1.93 & 4.67 & 6.75 \\
\hline 5 & Number of primary branches & 30.20 & 43.10 & 12.90 & 36.16 & 7.77 \\
\hline 6 & Length of primary branch $(\mathrm{cm})$ & 43.10 & 105.10 & 62.00 & 87.96 & 7.97 \\
\hline
\end{tabular}




\begin{tabular}{lllllll}
\hline SN & Traits & Min & Max & Range & Mean & CV (\%) \\
\hline 7 & Number of internodes of primary branch & 14.00 & 26.7 & 12.70 & 21.13 & 7.25 \\
8 & Internode length of primary branch $(\mathrm{cm})$ & 3.20 & 5.73 & 2.53 & 4.22 & 8.15 \\
9 & Number of secondary branches & 41.10 & 133.20 & 92.10 & 72.91 & 22.51 \\
10 & Leaf length $(\mathrm{cm})$ & 9.20 & 18.43 & 9.23 & 13.40 & 0.22 \\
11 & Leaf width $(\mathrm{cm})$ & 3.49 & 8.77 & 5.28 & 6.24 & 0.90 \\
12 & Leaf area $\left(\mathrm{cm}^{2}\right)$ & 24.63 & 105.45 & 80.82 & 57.96 & 0.27 \\
13 & Canopy diameter $(\mathrm{cm})$ & 76.70 & 164.60 & 87.90 & 134.46 & 9.95 \\
14 & Hundred bean weight $(\mathrm{g})$ & 11.00 & 16.50 & 5.50 & 13.53 & 3.43 \\
15 & Yield (g/plant) & 10.36 & 176.39 & 166.03 & 65.93 & 19.67 \\
\hline
\end{tabular}

In addition, Yigzaw [25] who studied genetic diversity among 16 arabica genotype at Finoteselam, reported that average green bean yield per tree varied from 144.6 to $566.7 \mathrm{~g}$ and 100 green bean weights ranged from 9.3 to $16.0 \mathrm{~g}$. In his study, tree height also varied from 107.5 to $182.8 \mathrm{~cm}$, canopy diameter from 137.1 to $246.5 \mathrm{~cm}$, trunk diameter from 24.6 to $39.6 \mathrm{~mm}$, number of primary branches per tree from 35.7 to 62.0 and number of secondary branches per tree from 21.3 to 117.7. Similarly, presence considerable to high phenotypic variation was observed in hybrid coffee from south western Ethiopia [10], in promising coffee cultivars from Wellega [7], on coffee landraces from Amaro at Awada center [8], in promising hybrid at highland Environments of Southwestern [11], on some specialty coffee cultivars [12], in coffee genotypes from Sidama [13], in coffee genotypes from Limmu area [19] and in coffee genotypes from Southwestern Saudi Arabia [24]. The slightest discrepancies in extreme values with the present study for some characters could be ascribed to differences in number and type of tested accessions, age of the tree and the location in which these studies were conducted. The presence of phenotypic variability among the accession reveals that there is a good chance of improving Hararge coffee accessions through selection and breeding. The prevalence of such variability in a predominantly self-pollinating species like C. arabica appears to be surprising. The variability may be attributed to evolutionary tendencies or natural mutation [18]

\subsection{Cluster Analysis}

The results of cluster analysis confirmed the presence of substantial variation among accessions. The 49 coffee accessions were grouped into five clusters (Table 3 ). The size of cluster varies from one accession in cluster IV and V to 34 accessions in cluster II. Cluster II and Cluster I represented $69.39 \%$ and $20.41 \%$ of the accessions Cluster V with coffee accession H11/04 showed the highest results for the majority of the characters (Table 4). For example, it had highest plant height $(159.90 \mathrm{~cm})$, number of internodes of main stem (23.5), number of primary branches (42.1), length of longest primary branches $(91.90 \mathrm{~cm})$, number of internodes of longest primary branches (23.2), average length of primary branches $(84.1 \mathrm{~cm})$, number of secondary branches (111.50), canopy diameter (139 $\mathrm{cm})$ and average green bean yield per plant $(176.39 \mathrm{~g})$. The result is in agreement with previous work $[10,7,11,8,12,13$, 19, 24]. Based on Mahalanobis's D2 statistics, highly significant $(\mathrm{p}=0.01)$ inter-cluster distances were obtained except between cluster I and II (Table 5). Cluster III showed the maximum and significant genetic distance (181.80) from cluster V. Furthermore, the inter-cluster distances between clusters III and IV, I and III, II and V, II and III, I and IV, II and IV, IV and V in that order were found to be highly significant. Crossing of parental lines extracted from germplasm accessions belonging to different clusters of wide Mahalanobis distance (D2) could maximize opportunities for transgressive segregation as there is a higher probability that unrelated accessions would contribute unique desirable alleles at different loci. Therefore, the present study suggests that the germplasm accessions from cluster I and cluster V, I and IV and IV and V could offer relatively better potential parental lines that, when intercrossed, could produce hybrids with maximum heterotic value. Most of the high yielding accessions were grouped in cluster I. So, we can also cross accessions in this cluster with each other.

Table 3. Clustering patterns of 49 coffee accessions based on 15 quantitative characters.

\begin{tabular}{|c|c|c|c|c|c|c|c|c|}
\hline \multirow{2}{*}{$\begin{array}{l}\text { Cluster } \\
\text { I }\end{array}$} & \multirow{2}{*}{$\begin{array}{l}\text { No. } \\
10\end{array}$} & \multirow{2}{*}{\begin{tabular}{|l}
$\%$ of acc. \\
20.41
\end{tabular}} & \multicolumn{6}{|c|}{ Name of Accessions } \\
\hline & & & $\mathrm{H}-02 / 04$ & $\mathrm{H}-21 / 04$ & H-25/04 & $\mathrm{H}-32 / 04$ & H-46/04 & . \\
\hline & & & $\mathrm{H}-18 / 04$ & H-23/04 & H-29/04 & $\mathrm{H}-34 / 04$ & H-618/98 & . \\
\hline \multirow[t]{6}{*}{ II } & 34 & 69.39 & $\mathrm{H}-01 / 04$ & H-12/04 & H-19/04 & $\mathrm{H}-28 / 04$ & H-37/98 & H-44/04 \\
\hline & & & $\mathrm{H}-03 / 04$ & H-13/04 & $\mathrm{H}-20 / 04$ & $\mathrm{H}-30 / 04$ & H-38/98 & H-45/04 \\
\hline & & & $\mathrm{H}-04 / 04$ & H-14/04 & $\mathrm{H}-22 / 04$ & H-31/04 & H-39/98 & H-47/04 \\
\hline & & & $\mathrm{H}-05 / 04$ & H-15/04 & $\mathrm{H}-24 / 04$ & $\mathrm{H}-33 / 04$ & H-40/98 & H-48/04 \\
\hline & & & $\mathrm{H}-06 / 04$ & H-16/04 & $\mathrm{H}-26 / 04$ & $\mathrm{H}-35 / 04$ & H-41/98 & \\
\hline & & & $\mathrm{H}-07 / 04$ & H-17/04 & $\mathrm{H}-27 / 04$ & H-36/04 & H-43/98 & \\
\hline III & 3 & 6.12 & $\mathrm{H}-08 / 04$ & $\mathrm{H}-42 / 04$ & 74110 & & & \\
\hline IV & 1 & 2.04 & $\mathrm{H}-09 / 04$ & & & & & \\
\hline $\mathrm{V}$ & 1 & 2.04 & H-11/04 & & & & & \\
\hline
\end{tabular}


Table 4. Cluster means of the 49 coffee accessions studied for 15 quantitative traits.

\begin{tabular}{|c|c|c|c|c|c|c|}
\hline SN & Traits & I & II & III & IV & $\mathbf{V}$ \\
\hline 1 & Plant height $(\mathrm{cm})$ & 150.02 & 146.80 & 114.40 & 150.50 & 159.90 \\
\hline 2 & Number of internode of main stem & 21.34 & 20.70 & 19.73 & 21.30 & 23.50 \\
\hline 3 & Internode length of main stem $(\mathrm{cm})$ & 7.08 & 7.16 & 5.83 & 7.11 & 6.81 \\
\hline 5 & Number of primary branches & 37.06 & 35.93 & 33.17 & 38.10 & 42.10 \\
\hline 6 & Length of primary branch $(\mathrm{cm})$ & 89.97 & 89.65 & 62.93 & 81.30 & 91.90 \\
\hline 7 & Number of internodes of primary branch & 22.55 & 21.03 & 16.83 & 21.10 & 23.20 \\
\hline 9 & Number of secondary branches & 70.16 & 73.06 & 47.43 & 133.20 & 111.50 \\
\hline 10 & Leaf length $(\mathrm{cm})$ & 13.35 & 13.39 & 10.48 & 13.35 & 12.51 \\
\hline 11 & Leaf width (cm) & 6.20 & 6.41 & 4.37 & 6.58 & 6.08 \\
\hline 12 & Leaf area $\left(\mathrm{cm}^{2}\right)$ & 56.51 & 60.77 & 33.60 & 57.62 & 50.12 \\
\hline 13 & Canopy diameter $(\mathrm{cm})$ & 136.45 & 137.56 & 92.6 & 129.8 & 139.10 \\
\hline 14 & Hundred bean weight (g) & 14.21 & 13.47 & 13.00 & 11.00 & 13.00 \\
\hline 15 & Yield (g/plant) & 115.48 & 50.64 & 29.57 & 88.99 & 176.39 \\
\hline
\end{tabular}

Table 5. Generalized squared distance among clusters for 49 coffee accessions.

\begin{tabular}{|c|c|c|c|c|c|}
\hline Cluster & I & II & III & IV & $\mathbf{V}$ \\
\hline I & - & 13.68 & $88.42 * *$ & $48.37 * *$ & $37.69 * *$ \\
\hline II & & & $57.30 * *$ & $43.58 * *$ & $74.99 * *$ \\
\hline III & & & & $117.52 * *$ & $181.80^{* *}$ \\
\hline IV & & & & & $41.39 * *$ \\
\hline V & & & & & \\
\hline
\end{tabular}

$*=$ Significant at 0.05 probability level $\left(\chi^{2} 15=25.00\right) * *=$ Significant at 0.01 probability level $\left(\chi^{2} 15=30.58\right)$.

\section{Conclusion and Recommendation}

There is considerable phenotypic variation in coffee accessions grown in eastern Ethiopia. The presence of phenotypic variability among the accession reveals that there is a good chance of improving Hararge coffee accessions through selection and hybridization. The variability may be attributed either to evolutionary tendencies, as the species is indigenous to Ethiopia, or to the natural mutations occurring to the population of the crop. It is advisable to maintain these coffee accessions and evaluate them for yield and cup quality, disease resistance, moisture stress tolerance, in future studies.

\section{Acknowledgements}

The authors would like to thank the Mechara Agricultural Research Center for financing the study.

\section{References}

[1] NBE. 2019. National Bank of Ethiopia Annual Report of the year 2017/18, PP. 67-69.

[2] FAO. 2020. Food and Agricultural Organization FAO data base by crop, area, yield and production. Food and Agricultural Organization. Available on: http://faostat.fao.org/site/567/DesktopDefault.aspx ?Page $\mathrm{ID}=567$ \# ancor.

[3] Bayeta, B., Labouisse, J P., Hamelin, C., Kotecha, S. and Bertrand, B. 2007. Collection and ex-situ conservation of coffee landraces in Ethiopia: The example of harerge In: $21^{\text {st }}$ International Conference on Coffee Science, Montpellier
(France), $11^{\text {th }}$ to $15^{\text {th }}$ September 2006. ASIC, Pp. 926-930.

[4] Taye, K. 2017. What Make Ethiopian Coffees Special: A View from Coffee Research, 15th African Fine Coffee Conference \& Exhibition Reshaping the African Coffee Industry for Productivity \& Investment February 15-17/2017, Millennium Hall, Addis Ababa, Ethiopia.

[5] Brown bridge, J M. and Eyassu, G. 1968. The quality of some of the main Ethiopian mild coffees. Turialba. 18: 361-372.

[6] Demel, T. and Assefa, T. 1994. A Study of Landraces of Harer Coffee in Eastern Ethiopia. Proceeeding of $13^{\text {th }}$ Plenary Meeting of AETFAT, 1: 161-169.

[7] Dawit, M. 2018. Genetic Diversity Analysis among Promising Wollega Coffee (Coffea arabica l.) Selections in Western Ethiopia. MSc. Thesis of Hawassa University. Thesis Submitted to Graduate Studies of in partial fulfillment of Hawassa University, Hawassa Ethiopia. P38.

[8] Desalegn, A. 2018. Genetic Variability and Character Association of Amaro Coffee (Coffea arabica 1.) Accessions at Awada, Southern Ethiopia. Thesis Submitted to Graduate Studies of Jimma University, Jimma, Ethiopia.

[9] FAO. 1968. FAO coffee mission to Ethiopian 1964 to 1965. Food and Agriculture Organization of the United Nations, Rome.

[10] Ayano, A., Sentayehu, A. and Abush, T. 2014. Combining Ability for Yield and Morphological Characters in Southwestern Ethiopian Origin Coffee Hybrids. Sky Journal of Agricultural Research, Vol. 3 (7): 128-136.

[11] Fekadu, T., Sentayehu, A. and Dagne, W. 2016. Assessment of the Growth and Yield Characters of Some Promising Arabica Coffee Hybrids under Highland Environments in Southwestern Ethiopia. American-Eurasian J. Agric. \& Environ. Sci., 16: 917-923. 
[12] Getachew, W., Sentayehu, A. and Taye, K.. 2013. Genetic Diversity Analysis of Some Ethiopian Specialty Coffee (Coffea arabica L.) Germplasm Accessions Based on morphological Traits. Time Journals of Agriculture and Veterinary Sciences, 1: 47-54.

[13] Gizachew, A., Hussien, M. and Taye, K. 2017. Genetic Variability of Sidama Coffee (CoffeaArabica L.) Landrace for Agro-morphological Traitsat Awada, Southern Ethiopia Academic Research Journal of Agricultural Science and Research, 5: 263-275.

[14] Hill, J, Becker, H. and Tigerstedt, P. 1998. Quantitative and Ecological Aspect of Plant Breeding. Chapman \& Hall, UK, London, $275 \mathrm{p}$.

[15] IPGRI. 1996. Descriptors for Coffea sp. and Psilanthus sp, International Plant Genetic Resource Institute, Rome, 36 p.

[16] Mahalanobis, P. 1936. On the generalized distance in statistics. Proc. Natl. Sci. India, 2: 49-55.

[17] Masreshaw, Y. 2018. Genetic Variability Study in Yayu Coffee (Coffea arabica L.) Germplasm Using Morphological Traits at Metu, Southwestern, Ethiopia. Thesis Submitted to Graduate Studies of Jimma University, Jimma, Ethiopia. PP. 62.

[18] Avice, J. and Hamric, J. 1997. Conservation Genetics: Case histories from nature. Chapman \& Hall Cop., New York.

[19] Olika, K., Sentayehu, A., Taye, K. and Weyessa, G. 2011.
Variability of quantitative Traits in Limmu Coffee (Coffea arabica L.) in Ethiopia. International Journal of Agricultural Research, 6: 482-493.

[20] SAS. 2002. Statistical Analysis Systems SAS/STAT user's guide Version 9 Cary NC: SAS Institute Inc. USA.

[21] Singh, R. and Chaudhary, B. 1979. Biometrical Methods in Quantitative Genetic Analysis. Kalyani Publishers, New Delhi.

[22] Smith, JS. 1889. and Smith O S. The description and assessment of distances between inbred lines of maize: The utility of morphological, biochemical and genetic descriptors for the testing of distinctiveness between inbred lines. Maydica, 34: 151-161.

[23] Coste, R. 1992. Coffee: the plant and the product. Macmillan Press Ltd., London, 328 p.

[24] Tounekti, T, Mahdhi, M., Al-Turki, T. and Khemira, H. 2017. Genetic Diversity Analysis of Coffee (Coffea arabica L.) Germplasm Accessions Growing in the Southwestern Saudi Arabia Using Quantitative Traits. Natural Resources, 8: 329.

[25] Yigzaw D. 2005. Morphological Variation among Ethiopian Coffee genotype. Part of thesis submitted for the Philosophiae Doctor, PhD. degree at the University of the Free State. South Africa. Pp. 43-67.

[26] IPGRI. 1996. Description for Coffea sp. and Psilanthus sp, International Plant Genetic Resource Institute, Rome. 